\title{
POPULATION POLICY IN A REGIONAL CONTEXT
}

\author{
Robert D Dean and Donald E. Pursell*
}

Memphis State University

\section{INTRODUCTION}

These past few decades, we have been living in what J. R. Hicks describes as the "age of growth, "where more goods and services, more labor to produce these goods and services, and above all, more people to consume them are in and of themselves very good things! 1 Population size and growth, of course, have long been identified with a nation's prosperity and strength. Adam Smith considered a growing population essential for a progressive and expanding economy, ${ }^{2}$ while Keynes stressed the importance of a growing adult population because it would encourage the maintenance or even expansion of the existing level of investment in new capital equipment and hence keep the economy from plunging into a state of chronic or stagnant unemployment. 3

Not all economists, however, have been sooptimistic about the role population plays in the development of the economy. Thomas Malthus pointed out that population growth tends to proceed at a faster pace than productivity, thus causing a labor surplus condition which eventually impedes if not stops economic development. ${ }^{4}$ John Stuart Mill, the last of the classical school, also echoed Mathus' thoughts, although in a somewhat different vein. More precisely, Mill maintained that population growth was not a necessary condition for human improvement since there was no reason to believe that moral and social progress improvement of the industrialarts, etc., could not take place in a stationary state of population, capital and wealth. 5 Mill, it might be added,was a strong advocate of birth control which prompted Thomas Moore, the English poet, to write in his poem,

\section{ODE OF THE GODDESS CERES:}

There are two Mr. Mills, whom those who like reading

What's vastly unreadable, call very clever;

And whereas Mill senior makes war on good breeding

Mill junior makes war on all breeding whatever.

Amidst the extensive discussion on population size, the growth or lack of growth, and the merits or demerits associated with each of the se policies, one seldom finds any serious discussion among economists on the problem of population distribution. Moreover, the spatial distribution is generally assumed to be optimal, at least this seems to be the implicit as sumption. Today, little more is known of the optimum distribution of population than when Wicksell que ried: "What density of population under given circumstances is most advantageous?" Population density distribution still seems to be characterized as an "empty box. "7

In the United States and especially the countries of Western Europe, however, the concern over population distribution is now rising to the forefront. James Sundquist, writing in The Public Interest, asks whe re are the estimated 100 million people that will be added to the U.S. population in the next three decades going to live? 8 Will they simply be added to the four hugh agglomera-

*Robert D. Dean and Donald E. Pursell, Department of Economics, Memphis State University. 
tions that presently contain 60 percent of our total population (but only use up 11 percent of the land) or will they be distributed more evenly throughout the nation? 9 President Nixon's task force on national goals has expressed alarm over the pattern of pop lation distribution that is evolving in this country. It cites the growing populationimbalance between urban and rural areas, small and large cities, central cities and suburbs, lagging and fast growing regions, etc., and points out that over 500 counties in the U.S. are now experiencing natural decreases in population (i.e., deaths greater than births) because of the continued outflow of young adults from these areas. 10 Peter Morrison makes an important point when he argues that a population crisis in this country in the next three decades will not be caused by sheer numbers or growth but by population maldistribution and concentration. ${ }^{11}$ Following Morrison's argument, we could not expect the highly popular policy of "zero population growth, "or any population g rowth stabilization policy for that matter, to solve the population imbalance between various regions of the country.

Not only is population distribution given short shrift by economic students of population, but the concern over population composition (i.e., sex, age, race, socio-economic status, etc.) from a policy point of view appears to be virtually non-existent. And yet, many of our current problems can be traced to the growing number of young people in our society as well as the steady increase in older persons whose incomes are generally too low to maintain a decent standard of living: 12

Moreover, when looked at spatially, the population composition, especially in terms of age, will most likely be unevenly distributed. In particular, a large portion of the very young (i.e., those persons 18 and under) will be concentrated in our major urban areas, thus placing even heavier burdens on these areas to properly care for the health, education, and general welfare of their youngest and most active citizens. In addition, young adults of working age will be relatively limited in supply in our smaller cities and rural areas, thus stripping these places of the manpower necessary for sustained economic growth. In many respects, therefore, the spatial imbalance of the "age composition" is the mostcrucial policy issue of all since the main source of manpower and population growth are the young adults, and without a sufficient number in this age group, any region is doomed to economic stagnation.

Although the need is great, the U.S. appears to be one of the last of the inore developed countries to become interested in formulating a national policy of population growth and distribution. Indeed, the first national commitment to an attack on population problems came onlyas recently as June 1969, when President Nixon delivered the first presidential message of population to the Congress. 13

Despite this ostentatious but rather late beginning, however, the formulation of a comprehensive population policy and plan for the Nation and its major regions appears no closer to being a reality than it was in 1969 . Although we could cite many reasons for this delay (not the least of which may be a low funding priority and the shortlife of the Commission), the authors would argue that a major part of the problem in developing a sound population policy is the need for a more thorough analysis of what the problem is. Even more important, we must devise a better conceptual framework to deal with population problems and the development of policy objectives. Moreover, this framework should have a spatial orientation since the population problems this country faces are basically those of population concentration and distribution. 
A major purpose of this paper, therefore, is to develop a conceptual framework for population policy and planning strategies at the national level but in a regional context. We stress the regional aspect because policy requirements at sub-national levels will in all likelihood be quite different. In addition, our intent is to examine the major elements of the population problem, i.e., population growth, population distribution and population composition and show how changes in these elements through variations in birth rates, death rates, and migration can effect the population profile of a region. Finally, we shall consider some national population policies and programs and consider how these policies and programs might work at the regional level.

\section{POPULATION DISTRIBUTION}

Of the three population variables, births, deaths, and migration, migration seems likely to be the more important over the next decade, or decades. The dimensions of migration are more apparent when simple calculations are made to illustrate the probable number of migrants of the 1970's. Regional migration statistics indicate that 26 percent of the working population worked in a different place in 1965 compared to place of work in $1960 .{ }^{14}$ Another 4 or 5 percent of the population probably moved from place of work in 1960 to another destination, only to return to their original place of work in 1965. Taking the return migrant into account, one could reasonably assume that 30 percent of the work force will change its place of work at least once each five-year interval during the 1970's. Applying a scaled-down fraction of this coefficient to the population and breaking migration into five-yearintervals indicates that approximately 35 to 45 million persons are likely to migrate from 1970-1975, and an additional 37 to 47 million are likely to migrate from 1975-1980. For the decade of the 1970's, redistribution of the existing population is likely to approximate 80 to 90 million individuals, or approximately 40 percent of the 1970 population. When one considers the magnitude of the redistribution likely to occurin the 1970's, and when one considers the present diseconomies and disorders in some of our existing cities, then the urgency for developing a rational regional population policy is more apparent. 15

One other point is worth emphasizing here while we are looking at the simple arithmetic of migration of the 1970's and that is the concept of zero population growth. Even if zero population growth were achieved in the near future, a much discussed topic today, population problems would likely remain because of the internal redistribution which is constantly occuring. 16

To focus on the problems that develop as a result of regional redistribution to population, let us postulate a closed economy with two regions, one growing and developing, Region A, and one declining, Region B. Assume that both regions start in period t with similar resources, a similar private capital structure and level, and a similar public infrastructure. In periods $t+N$, B exports, on net balance, people to $A$. The private returns to individuals migrating from $B$ to $A$ may be assumed positive. The question we now propose is what are the effects of several years of this population redistribution?

Migration, being a selective process, is likely to have substantially affected the age structure of the two regions. Region Awill show a relatively larger proportion of its population in the younger adult age group, i. e., 2544 , the more productive years of the life span. ${ }^{17}$ Since these arealso the years of heavier reproduction and development of children (primarily school years), Region A will also have to provide additional public infrastructure 
to educate its children. Private capital must also be increased in Region A due to increased housing demand, and public capital expenditure will also be heavier as more facilities to service the housing are provided and as additional schools are constructed. Providing the necessary infrastructure may become increasingly costly to Region A if the returns to scale in Region A are constant or decreasing, or if the public sector must place higher priced bids for control of the resources necessary to build the required infrastructure. The difficulty in increasing the productivity of public services, such as school teachers, suggests that indeed the returns to scale may be decreasing.

Exporting population from Region B to A will have certain predictable effects upon B. B's age structure of the populationwill be adverselyaffected. Migration will leave behind many of the older less capable members of the labor force. The labor forcewill age, meaning that public supported projects' costs will fall proportionately greater on working aged groups since a larger proportion of Region B's inhabitants will have limited means due to their being on pensions. Private capital will depreciate and be permitted to deteriorate more rapidly in Region $B$ than in Region A, for the uncertainty over Region B's future will encourage profit maximizers or loss minimuming individuals to reduce investment in Region B. Public capital infrastructure will likely be less intensively used in Region B. As Region A builds new schools, Region B's schools are likely to be underutilized relative to Region A's use of such facilities. The reduced proportion of the labor force in Region B will impede this region's ability to maintain its infrastructure. The larger proportion of persons aged 60 and over in Region B will interfere with Region B's ability to raise public funds.

In addition to selecting out the youngest members of Region B's labor force for export to Region A, migration out of $B$ is likely to have a greater impact on $B$ in that the more creative individuals are likely to leave $B$ in greater numbers. Let us assume that we can divide the population into two groups, alpha types and beta types. The alpha types a re the entrepreneurs, the organizers, the employers or movers of the economy; while beta types are less creative, non-entrepreneurial individuals, or employees (include most college deans in this latter group). There will probably always be an interchange of alpha types between regions regardless of whether a region is growing or declining. If, however, the net migration of alpha individuals out of Regional B falls below a centain "critical minimum" level, then the stagnation and decline in Region B may become self-sustaining. A failure to introduce a sufficient number of new alpha types into Region B may damage leadership abilities to the extent that Region B will be unable to recover until a larger number of alpha individuals a re integrated into its economy.

This examination of Regions A and B may best be summarized by asking this question: Is it rational, i. e., an optimum use of resources, to permit Region A to build private and public facilities and probably to undergo overutilization of these resources in the short run while Region B's capital structure deteriorates, is underutilized, and becomes increasingly dilapidated?

This question can perhaps only be answered by examining migration from the individual's point of view and from society's point of view. The decision to be mobile or immobile represents individual choice based upon individual estimates of the benefits and costs involved in mobility. The resulting migration vectors, although they probably maximize individual utility, 18 may fail to maximize social utility for a region (either receiving or exporting) and may have a cost-benefit schedule such that receiving or exporting population may or may not be to that region's gain. 
In order to delineate the elements more clearly, let us as sume that migration is based upon the following is sues: 19

\section{PRIVATE}

$B_{p}$ - represents an estimate of the utility derived from a given move for the Jth migrant.

$\mathrm{C}_{\mathrm{p}}$ - represents an aggregate estimate of the costs (disutility) attached to the move of the Jth migrant.

$\mathrm{N}_{\mathrm{p}}$ - sum of $\mathrm{B}_{\mathrm{p}}+\mathrm{C}_{\mathrm{p}}$, or net private benefits accuring to Jth migrant.

PUBLIC

$S_{p}$ - represents an aggregate estimate of the utility to society from the move of the Jth migrant.

$S_{c}$ - represents the cost (disutility) to society resulting from the move of the Jth migrant.

$N_{S}$ - sum of vectors $S_{p}+S_{c}$ and represents the net gain to society or benefits from the move of the Jth migrant.

The $\mathrm{N}_{\mathrm{p}}$ and $\mathrm{N}_{\mathrm{s}}$ functions are assumed to be governed by diminishing $\mathrm{re}-$ turns, thus the negative slope of these functions.

Migration may be judged beneficial, i. e., as a force augmenting income if $N_{p}=N_{s} \cdot 20$ (See Figure 1.) The net gain to individuals as a result of migration could stimulate a net gain to society as well.

On the other hand, the amount of migrationoccurring may be less than desirable. That is, individuals may be unable to perceive of superior opportunities because of incorrect assessments of the opportunities. Sucha situation may develop through faulty or imperfect information. Consequently, mobility is restricted to some level below the desired level. This situation is depicted in Figure 2. Individuals can perceive aggregate benefits only to point $A$ whereas society can perceive benefits through mobility to point $B$. The zone $A B$ can then be defined as the gap between what private individuals see as the net return to theirmobility and what society sees as the return in a public sense to mobility. Regional population policy in this context would call for the dissemination of better information on the opportunities available between regions $i$ and $j$, as population policy takes the form of stimulating mobility. The $N_{p}$ vector should be shifted to $N_{p}^{\prime}$ assuming $N_{s}$ is correct.

Not all mobility or redistribution of population is likely to benefit society at all times. ${ }^{21}$ This is likely to be the case where the net private returns to mobility exceed the net social returns to mobility. Figure 3 depicts this situation. The individual mobility vector would push the net benefits to migration to zero at point $Q$. Society calls for less migration in that the net public benefits are reduced to zero at point $R$. The region $Q R$ now defines an area of disagreement where the individual is interested in carrying migration to a greater extent than society deems rational. In this situation, the individual is induced to become mobile by higher net rewards but the result of his movement, in net terms, is to add a heavier burden for public goods in the receiving area, the consequent reduction in use of the public goods in the exporting areas amounting to an additional misallocation of public goods. Regional population policy in this context might be geared to encouraging private companies and public agencies to locate in the labor exporting areas, or in an extreme case, policy might dictate that a firm continue rather than shut down, thereby offering greater rewards for individuals in this area and reducing the private $B_{p}$ function. $N_{p}$ can then be shifted to the right. 
BENEFITS/MIGRANT

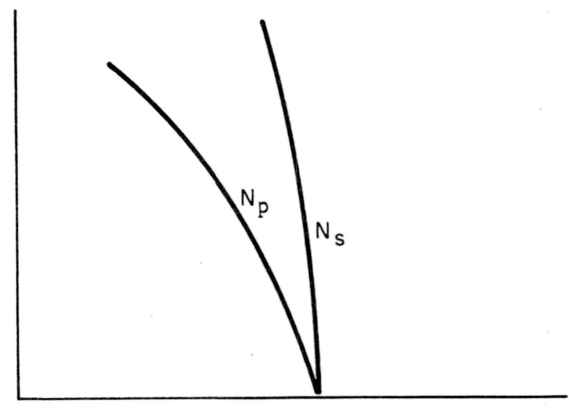

NUMBER OF MIGRANTS

Figure 1

Figure 2

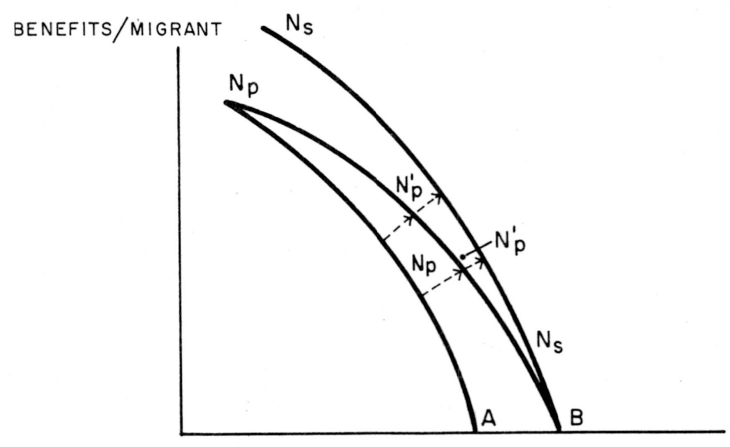

NUMBER OF MIGRANTS

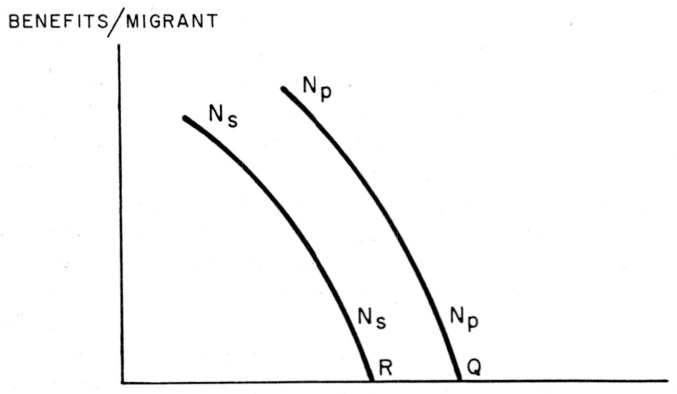

Figure 3

NUMBER OF MIGRANTS 


\section{POPULATION GROWTH AND COMPOSITION}

Differential population growth rates through natural increase will also have a direct bearing on the population structure of a region. The impacts of three different growth rates are shown in Table 1.

Beginning in 1970 with a population of 2.5 million and with an age structure similar to that recorded in the 1970 Census, the effects of alternative population growth rates are indicated for Regions A, B, and C. A 1 percent annual growth rate augments the population 10.5 percent over the decade of the 1970 's, a 1.5 percent rate augments the population by 16 percent, while a 2 percent growth rate increases total population by 21.9 percent. The more significant change, however, occurs in the age composition of the population. Under the assumption of a 1 percent rate of growth, the proportion of the population under 20 years of age would be 25.9 percent in $1980,29.5$ percent under the 1.5 percent growth rate, and 33.2 percent under the 2 percent annual growth assumption. The dependency ratio, an appropriate indicaticn of the number of potential workers to the number of non-workers, i. e., younger and older persons, would be 176.2 under the 1 percent growth rate in 1980 , 154.6 under the 1.5 percent growth rate, and 137.0 under the 2 percent rate of growth. 22 In general, the larger the dependency ratio the more favorable contribution the age composition of the population makes to economic growth. As Table 1 indicates, the problems of rapid population growth a re compounded if the growth rates are carried forward another ten years.

Summing up, differential rates of populationg rowth will affect age composition of the population as well as its size. The higher the birth rate the higher the ratio of non-productive to productive workers in a given region over given period of time, and hence the greater the burden on the productive members of society for social overhead improvements. Higher growth rates, if sustained, will lead to larger concentrations of population and inevitably to a deterioration of the social and physical environment unless increasingly larger amounts of resources are diverted from the private to the public sector. On the other hand, if a policy of selective growth rates is used, less concentrated regions with good development potential can be encouraged to accelerate population growth, while the more congested regions are induced to stablize their populationgrowth. In this mannera more balanced distribution of the population can be achieved.

\section{POPULATION POLICIES AND PROGRAMS}

The United States has always had a population policy of one sort or another even though this policy has been unenuniciated and certainly uncoordin nated. With regard to population growth, the formative years of the country's development were characterized by the need for more people to till the soil, fight Indians, acquire and protect new territories, etc.; therefore, families were large and immigration was encouraged. Near the turn of the nineteenth century, the policy of stimulating immigration slowly began to change and by 1921 specific quota laws limiting the number of immigrants from various European countries were in effect. The nationalorigins quota system was abolished in 1965, however, and a subsequent rise in immigration has followed. Indeed in 1969, roughly 20 percent of the nation's total population growth was accounted for by immigration. Furthermore, the Bureau of the Census estimates that by 1975 more than 70 percent of the net flow of migrants into metropolitan areas will be foreign immigrants. ${ }^{3} \mathrm{Cl}-$ early immigration must be a major consideration in any national or regional population policy. 
TABLE 1. HYPOTHETICAL AGE STRUCTURE OF POPULATION ASSUMED

2, 500,000 IN 1970 UNDER DIFFERENT GROWTH RATE ASSUMPTIONS

\begin{tabular}{|c|c|c|c|c|c|c|c|c|c|c|c|c|c|c|}
\hline & & & $1 \%$ & $\begin{array}{l}\text { Regi } \\
\text { nual }\end{array}$ & $\begin{array}{l}\text { n A } \\
\text { ate of Gror }\end{array}$ & & $1.5 \%$ & $\begin{array}{r}\text { Reg } \\
\text { Annua }\end{array}$ & $\begin{array}{l}\text { on } B \\
\text { Rate of Gro }\end{array}$ & & $2 \% \mathrm{Ar}$ & $\begin{array}{r}\text { Reg } \\
\text { hual }\end{array}$ & ate of Grow & \\
\hline Age & 1970 & $\%$ & 1980 & $\%$ & 1990 & $\%$ & 1980 & $\%$ & 1990 & $\%$ & 1980 & $\%$ & 1990 & $\%$ \\
\hline $0-19$ & 947,500 & 37.9 & 715,288 & 25.9 & $1,058,350$ & 34.7 & 854,978 & 29.5 & $1,377,922$ & 40.9 & $1,011,203$ & 33.2 & $1,724,995$ & 46.4 \\
\hline $20-64$ & $1,310,000$ & 52.4 & $1,761,837$ & 63.8 & $1,662,250$ & 54.4 & $1,761,837$ & 60.7 & $1,660,178$ & 49.3 & $1,761,837$ & 57.8 & $1,660,605$ & \\
\hline $\begin{array}{l}65+ \\
\text { Total }\end{array}$ & 242,500 & 9.7 & 284,435 & 10.3 & 329,400 & 10.8 & 284,435 & 9.8 & 329,400 & $\begin{array}{r}4 . .3 \\
9.8\end{array}$ & $\begin{array}{r}1,161,831 \\
284,435\end{array}$ & $\begin{array}{r}5 / .8 \\
9.3\end{array}$ & $\begin{array}{r}1,660,605 \\
329,400\end{array}$ & $\begin{array}{r}44.7 \\
8.9\end{array}$ \\
\hline $\begin{array}{l}\text { Population } \\
\text { Dependency }\end{array}$ & $2,500,000$ & & $2,761,500$ & & $3,050,000$ & & $2,901,250$ & & $3,367,500$ & & $3,047,475$ & & $3,715,000$ & \\
\hline Ratio & & & 176.2 & & 119.8 & & 154.6 & & 97.2 & & 137.04 & & 80.8 & \\
\hline
\end{tabular}


The U.S. has also indirectly supported a policy of population distribution since its founding. Through the subsidation of rivers, railroads, highways, protection from Indians, etc., the government induced people to move West, thus reducing the build-up of people along the East Coast. In more recent years, regional development programs, national, state, and local highway expansion programs, rural development projects, etc., have tried to stimulate the economic growth of depressed regions in hopes of stemming the net out-migration of population from these areas. 24

Despite these past attempts, it is quite clear that no cohesive or comprehensive population policy for the United States and its sub-regions has ever really existed. Moreover, past as well as present population policy appears contradictory in terms of objective and application. Take, for example, the current effort by $\mathrm{HEW}$ to carry out mortality reduction programs. These programs often center a round regional health demonstration projects which are designed to coordinate Federal and state resources to provide a certain minimum level of health care. The objectives of these programs is usually to reduce mortality rates to levels more comparable to national levels by improving the health care available throught existing private and public facilities. Preventive health care is also used to reduce mortality by improving centain public facilities such as the water system or sewage treatment facilities. Despite the noble objective of these programs to reduce the death rate, they must in reality be classified as programs which tend to augment population and hence must be associated with a policy of population growth, however marginal their ultimate impact may be.

Probably the greatest public policy stimulant to increasing population, but not recognizedas such, are the Federal and state tax laws. Personal exemptions a re provided under Federal and state tax statutes which reduce the cost of rearing children by providing that a minimum amount of income be potentially reserved for children. The personal expenses associated with a birth is tax deductible under the medical provision of the Federal tax law, as well as being deductible under most state tax laws. These provisions act as subsidies which affect resource allocation, income distribution, and the number of children a family decides to rear. If the birth subsidies from the tax laws operate similar to the manner in which the tax subsidies on housing operate, then our population is larger than it would havebeen in the absense of tax advantages. If birthsubsidies stimulate population one-half the extent to which tax benefits stimulated additional housing consumption, then the annual birth rate for the past several years has probably been 10 percent above what it would have been in the absence of the tax advantages. 25 If one accepts this 10 percent figure and assumes that it had not been in effect over the past 25 years, then the 1970 population would be a round the magnitude of $197 \mathrm{M}, 6$ million less than the actual 1970 total. If tax advantages have pushed birth rates 15 percent above what they would have been in the absence of tax advantages, then the 1970 population would have been approxímately 9 million less than was recorded in 1970 .

While population growth is stimulated by one set of policies, an additional set acts to reduce or even halt population growth. Presidential Commissions, Congressional Commissions, as well as various private and semi-private organizations seek to reduce population growth. The White House Commission on Population Growth and America's Future last month strongly recommended that population growth be considered with all due expediency. Noting that population growth to 300 million is virtually beyond our control to halt short of large-scale genocide or disaster, the Commission argued that we might be able to halt or restrict the growth of population to the 400 million mark. 
Public and private resources a re also used to combat the birth rate through Planned Parenthood Organizations. These groups conduct clinics to give contraception advice and dispense contraception articles, sometimes without charge, and they promote publicity campaigns aimed at reducing the number of unwanted pregnancies.

At the national and regional level, planned parenthood organizations have been linked together with hospitals and medical schools to form the institutional base for a national family planning program Unfortunately, family planning programs have as their goal the elimination of unwanted births, or in more positive terms, the enabling of couples to have as many children as they want! This number, in mostcases, is above the replacement level (i.e., two children per family); therefore, family planning coupledwith a successful regional program to lower mortality rates could indeed result in a higher rate of population growth for a particular region or area.

The very nature of family planning, however, makes one question whether or not it is that useful a tool for population planning. Family planning is essentially a volunta ry action; therefore, family size, the crucial variable in the population equation, depends upon the wishes and desires of each separate couple. As Kingsley Davis puts it, "there is no reason to expect that the millions of decisions about family size made by couples in their own in 6 terest will automatically control population for the benefit of society. " Moreover, since family planning does not attempt to tackle the knotty problem of "wanted births" in excess of the replacement level, it is questionable whether it can ever really be an effective instrument for population control. 27

The critical question for population stabilization, therefore, is what motivates couples to have children and beyond that what programs and policy actions can be developed which will keep family size at replacement levels. Certainly a society that looks upon childless or single-child homes as personal failures is not yet willing to accept a policy of population control. Further, when abortion laws and sterilization programs are considered repugnant and even criminal, it is doubtful if a policy of population stabilization would ever really be accepted. And yet, if we wish to keepfrom having much higher death rates in the future, we must heed Lincoln and Alice Day's advice and make every effort to establish the kind of social conditions which will encourage couples to keep their child bea ring within replacement levels. 28 In short, the attitudes and values associated with child bearing and family size must undergo significant change if population planning is to be a reality at both the national and regional levels.

Although there is no formal national policy concerning population distribution, a number of programs have been suggested or are in the process of being implemented by the Federal government which would have direct bearing on the regional distribution of population. Of current interest are the proposals dealing with growth centers and new communities. Growthcenter proponents argue that population can best be diverted from the highly concentrated areas of the country by encouraging the economic development of medium-sized cities (i.e., 25,000-50,000 persons) which have a strong economic base and good future growth potential. A variant of this proposal is to encourage and promote the growth of the small towns and rural places that are rapidly losing population to the larger urban areas. The argument here is that much of the working class would prefer to live in smaller communities because of the "better" conditions for raising their families; therefore, industry ought to be encouraged to locate spatially in such a manner as to support the stabilization or even growth of the population in these smaller areas. The other major strategy is to develop new towns or communities 
which would absorb the largest portion of the population growth over the next 30 years. These communities would be subsidized by Federal and state governments, bothin terms of financing and planning, and would presumably be located in proximity to other growth centers in order to achieve economic stability and integration. 29

There is a good deal of speculation as to whether or not a "growth center" or "new community" program could ever succeed in redistributing the population without sufficient inducements for people to move from the heavily populated regions to regions of less density. ${ }^{30}$ Although the Federal government has not seen fit to address itself to this problem, a number of advocates of a population distribution policy are convinced a majorprogram of relocation is both necessary and inevitable. William Coleman of the National Urban Coalition argues that resettlement allowances are urgently needed for low income families whose income is too low to support such a move. ${ }^{31}$ Peter Morrison further recommends that resettlement allowances be tied to the "friends and relatives" migration syndrome, i.e., resettlement allowances would be given to certain families and then these families would encourage relatives and friends to resettle near them. 32

Americans of all persuasions, however, are highly mobile (i. e., one out of every five moves to another house annually). Moreover, since the largest portion of migrants are young adults of child bearing age, who are generally responsive to the spatial distribution of economic activity, the re is somequestion whether or not resettlement allowances can do much to reduce regional population concentration unless the re is a concomittant redistribution of economic activity. This can only come about, of course, if both public and private decision makers are willing to invest rather heavily in the business development of smaller growth centers and less populated regions of the country.

\section{A FRAMEWORK FOR NATIONAL AND REGIONAL POPULATION POLICY}

From the foregoing discussion, it ought to be apparent that this country has no overall population policy, but rathera set of public programs that affect the size, growth, distribution, and composition of the population in a fragmented, inconsistent, and conflicting manner.

In this section of the paper, therefore, we shall attempt to construct a rather simple policy model which can be used as the basisfor establishing a more realistic framework for a national and regional population policy. Hopefully, this policy framework can be used to develop a more cohesive set of population programs and a more effective policy for population stabllization.

The policy model consists of a set of policy elements or variables, goals, criteria, and programs. The policy variables in the model are (1) population growth, (2) population distribution, and (3) population composition. These variables can be manipulated at both the national and regional level in order to achieve certain predetermined goals with respect to economic and social welfare. Because the interrelationships between the population policy variables, population programs, and national and regional welfa re goals a re somewhat complex, we shall not attempt to describe the model in all of its intricacies. Instead, we shall concentrate our analysis on a set of hypothetical policy and human resources accounts which are the cornerstones for our population policy framework. The policy matrix is illustrated in Table 2 .

For each region of the country, a population policy would be established that would have as its overall goal the maximization of the welfare of the region's inhabitants in terms of three major goals criteria: (1) the quality of 
the social and physical environment, (2) per capita income, and (3) income distribution. For each policy variable (e.g., population growth), a performance "rating" or "objective" would be established in terms of specific national and regional goals criteria. For example, suppose our goal is a "pollution-free" region and that we feel this goal is most likely to be attained with a zero population growth rate. Our performance objective, therefore, is a zero growth rate over the time period in which the goal is to be achieved. On the other hand, in order to raise per capita income and sustain economic growth, we may desire a population growth rate of 1.0 percent annually. Finally, to insure a more equitable distribution of income, we may come up with a third growth rate, say .05 percent. These conflicting growth rates would be resolved on the basis of the differential sums of net social benefits (Ns') plus net private benefits $(\mathrm{Np})$ resulting from each particular growth rate.

In addition, regional welfare objectives would be measured in terms of national objectives or standards so that area-wide conflicts can be resolved. Thus, if Region A wishes to adopt a zero population growth rate but national objectives call for a 1.0 growth rate, policy trade-offs must be made in order to achieve regional and national consensus.

Table 2. NATIONAL AND REGIONAL POPULATION POLICY MATRIX

\begin{tabular}{|c|c|c|c|}
\hline Policy Variable & $\begin{array}{l}\text { Quality of } \\
\text { Social and } \\
\text { Physical } \\
\text { Environment }\end{array}$ & $\begin{array}{c}\text { Economic } \\
\text { Growth }\end{array}$ & $\begin{array}{c}\text { Income } \\
\text { Distribution }\end{array}$ \\
\hline & $\begin{array}{l}\text { Objectives } \\
\text { Programs }\end{array}$ & $\begin{array}{l}\text { Objectives } \\
\text { Programs }\end{array}$ & $\begin{array}{l}\text { Objectives } \\
\text { Programs }\end{array}$ \\
\hline Population Growth & $\mathrm{O}_{1} \cdot \cdot \cdot \mathrm{O}_{\mathrm{n}}$ & $\begin{array}{l}\mathrm{O}_{1} \cdot \cdot \mathrm{O}_{n} \\
\mathrm{P}_{1} \cdot \ldots \mathrm{P}_{n}\end{array}$ & $\begin{array}{l}\mathrm{O}_{1} \cdot \cdot \cdot \mathrm{O}_{\mathrm{n}} \\
\mathrm{P}_{1} \cdot \cdots \cdot \mathrm{P}_{\mathrm{n}}\end{array}$ \\
\hline Population Distribution & $O_{1}^{1} \cdot \cdot \cdot O_{n}^{n}$ & $\begin{array}{l}O_{1} \cdot O_{n} \\
P_{1} \cdot . P_{n}\end{array}$ & $\begin{array}{l}O_{1}^{1} \cdot \cdot \cdot O_{n} \\
P_{1} \cdot \cdots \cdot P\end{array}$ \\
\hline Population Composition & $\begin{array}{l}1 \cdot \mathrm{O}_{1} \cdot \cdot \mathrm{O}_{\mathrm{n}} \\
\mathrm{P}_{1} \cdot \cdot \cdot \mathrm{P}_{\mathrm{n}}\end{array}$ & $\begin{array}{l}\mathrm{O}_{1} \cdot \mathrm{O}_{\mathrm{n}} \\
\mathrm{P}_{1} \cdot \mathrm{P}_{\mathrm{n}}\end{array}$ & $\begin{array}{l}\mathrm{O}_{1} \cdot \cdot \mathrm{O}_{\mathrm{n}}^{\mathrm{n}} \\
\mathrm{P}_{1} \cdot \cdot \cdot \mathrm{P}_{\mathrm{n}}\end{array}$ \\
\hline
\end{tabular}

To carry out policies consistent with regional and national welfare obm jectives, Federal, state and local programs affecting population growth, composition and distribution would be established and measured in terms of these objectives. It should be emphasized that the nature of these programs, i. e., mortality reduction programs vs. family planning programs, may differ markedly, but their aims will be one and the same. Thus, if the objective is a zero population growth rate in Region $A$, the family planning programs must be operating in such a fashion that birth rates will fall just enough to offset the decline in mortality rates.

It is readily seen that population policy in this type of model is a "tool" which can be used to attain targeted levels of social and economic welfare for the Nation and its regions. Moreover, the policy variables are treated as being exogenous, whichis quite necessary if we are ever to consider population planning as a serious endeavor. 33

Because population as a policy variable is treated exogenously to the system, we need a set of human resourceaccounts to monitor the effects of population policy on the structure of the population (which, in turn, is presumed to have certain effects on the region's social and economic conditions). A 
rather crude design of the human resource accounts is shown in Table 3 .

Although the number of items that could be placed within a human resource accounting framework is quite numerous, the indices shown in Table 3 are representative of the types of data that are needed to measure the effect of certain population policies on the size, growth, distribution, and composition of the regional population. Moreover, the above indices allow comparative analyses at the national level of the differences in outcome of the same or different regional population policies. Such feedback will help reorder program priorities as well as alter long-term national population policy.

In addition to population data, the human resource accounts would also include "vital statistics" or indices which measure changes in the region's level of social and economic welfare. These indices are listed at the bottom of Table 3. Through time series analysis, the welfare indices can be related to changes in population growth, composition and distribution between and within regions. The welfare indices also can be used to determine funding and program priorities with respect to special welfare criteria.

To be effective, the policy model described above requires the development of new organizations and institutions to deal with population problems and issues. At the national level, there needs to be established a population planning unit which would formulate national goals for population growth, distribution, and composition, perhaps through the Executive Office of the President and in conjunction with the President's Population Commission or through one of the existing departments, such as Health, Education, and Welfare, Housing and Urban Development, etc. The population planning staff would also assess regional population programs in light of national population goals and objectives, as well as prepare and submit to the President an annual population report as to progress made, problems encountered and future strategies needed to achieve a more orderly and balanced distribution of the Nation's population. At the state or multi-state level, a Department of Population Planning and Community Development should be established which would carry out functions similar to those of the population planning unit at the national level. At the state or multi-state level serious consideration should be given to providing the above departments with powers to acquire, hold and dispose of land deemed strategic for orderly population growth and distribution. Moreover, all state and local agencies carrying out programs in housing, health, industrial development, transportation, education and land use planning would of necessity have to consider the effects of these programs on population growth and distribution. The above Department would also be responsible for maintaining a set of human resource accounts at the regional level and where possible at sub-regional levels.

The policy model described above is indicative, we hope, of the type of approach needed to develop a more realistic framework for population policy decisions. It also suggests the urgency of the situation: we ought to begin the development of a population policy that is both broad in scope and national in implication immediately. Moreover, this policy should clearly strive to achieve a more balanced distribution of the population among the various regions of the country, which, in turn, will call for controlover regional population growth rates to the extent that the less congested regions are encouraged to grow at more rapid rates, while the more heavily populated regions are induced to stablize or even curtail population growth.

In order to achieve a more balanced distribution of the Nation's population, the Federal government in conjunction with state governments and multi-state regional development commissions should develop a comprehen- 
Population Size and Compositon

1. Total Population
Urban
Non-urban
Male
Female
White
Non-white
Under 18
$18-64$
65 and over

2. Percentage Composition

Urban
Non-urban
Male
Female
White
Non-white
Under 18
$18-64$
65 and over

3. Population Density (person/sq. mile)

Urban

Non-urban

Population Growth and Distribution

1. Population Growth

Urban

Non-urban

Male

Female

White

Non-white

Under 18

$18-64$

65 and over

2. Vital Rates

Births/1000 pop.

Deaths/100 pop.

Net Natural Increase/1000

$$
\text { pop. }
$$

3. Migration Rates

Urban/1000 pop.

Non-urban/1000 pop.

Male/1000 pop.

$$
\begin{array}{r}
2,000,000 \\
1,200,000 \\
800,000 \\
900,000 \\
1,100,000 \\
1,200,000 \\
800,000 \\
600,000 \\
1,000,000 \\
400,000
\end{array}
$$

$$
\begin{array}{r}
1,000,000 \\
400,000 \\
600,000 \\
480,000 \\
520,000 \\
700,000 \\
300,000 \\
350,000 \\
400,000 \\
250,000
\end{array}
$$

800,000

560,000

408,000

392,000

440,000

360,000

320,000

240,000

240,000

$60 \%$
$40 \%$
$45 \%$
$55 \%$
$60 \%$
$40 \%$
$30 \%$
$50 \%$
$20 \%$


TABLE 3. REGIONAL HUMAN RESOURCES ACCOUNTS

(Continued)

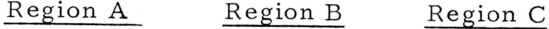

Female/1000 pop.

White/1000 pop.

Non-white/1000 pop.

Under 18

$18-64$

65 and over

\section{$9 \%$}

$5 \%$

$10 \%$

$8 \%$

$11 \%$

$7 \%$

$\begin{array}{rr}11 \% & 9 \% \\ 10 \% & 12 \% \\ 10 \% & 6 \% \\ 12 \% & 13 \% \\ 10 \% & 11 \% \\ 8 \% & 9 \%\end{array}$

Economic Growth and Income Distribution

1. Labor Force Partici-

$$
\text { pation Rate }
$$

2. Per Capita Income

3. Output (dollars) Per Capita (annual)

4. Public Expenditures/ Capita

5. Public Goods Production Function

Physical and Social Environmental Indicators

1. Level of Air Pollution

$$
\text { (Index) }
$$

1.5

1.0

2. Level of Water Pollution (Index)

3.5

2.0

1.5

30 years.

35 years

$25 \%$
$9 \%$

$2 \%$

$13 \%$

$9 \%$
3. Median Age of Housing

4. \% of Population Classified as Poor 
sive program of relocation of human resources and productive activity. Through resettlement allowances, investment tax credits, land use planning, manpower training allowances, highway construction, etc., workers and business firms must be attracted to growth centers in less congested regions that offer opportunities for economic profit and which have public infrastructures capable of sustaining growth.

These policy recommendations a re but a few of the many needed to move the Nation towards a philosophy of balanced population growth and distribution. It is hoped, however, that our thoughts and "value judgments" will motivate others to look more carefully at the population problems and issues facing our country and above all, to become interested in population policy as an interesting and exciting field of research for the future. 


\section{FOOTNOTES}

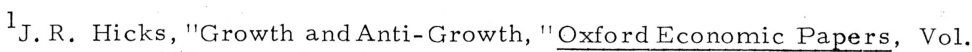
18, November 1966, pp. 267-269.

${ }^{2}$ Adam Smith, The Wealth of Nations, Book 1, Chapter 8, The Cannon Edition, Vol. i, p. 83 .

${ }^{3}$ John Maynard Keynes, The General Theory of Employment, Interest and Money (New York: Harcourt, Brace and World, Inc., 1964). Also see J. M. Keynes, "Some Economic Consequences of a Declining Population," Eugenics Review, April 1937, pp. 13-17.

${ }^{4}$ Thomas R. Malthus, An Essay on the Principle of Population, London, 1806.

${ }^{5}$ John Stuart Mill, Principles of Political Economy, Sir William Ashley, ed. (New York: August M. Kelly, 1909), p. 750.

${ }^{6}$ For a thorough review of the problems related to optimum population policies especially as they relate to population size rather than distribution, see J.E. Meade, Trade and Welfare, Chapter 6, Oxford University Press, 1955. For a non-spatial treatment of optimum population size under conditions of constant and diminishing returns to scale, see P.S. Dasgupta, "On the Concept of Optimum Population, "Review of Economic Studies, Vol. 36, July 1969, pp. 295-318.

${ }^{7}$ Knut Wicksell, Vorlesunger uber Nationalokonomie auf grundlage des Marginalprinzepa, quoted by Manuel Gottlieb, "The Theory of Optimum Population for a Closed Economy," Journal of Political Economy, 1945.

8 James L. Sundquist, "Where Shall They Live?" The Public Interest, No. 18, Winter 1970, pp. 88-100.

${ }^{9}$ The Urban Land Institutehas projected 187 million persons living in these four major agglomerations by theyear 2000. In particular, 68 million persons will residealong the Atlantic Seaboard in the region from Boston to Washington, D. C. Another 61 million will be found along the base of the Great Lakes stretching from Ithaca, New York, to Green Bay, Wisconsin. An additional 44 million will live on the Pacific Coast, bounded in the south by San Diego and in the north by San Francisco. The final 14 million will be located in Florida within the Jacksonville-Miami and Tampa-St. Petersburg metropolitan belts. For further details, see National Commission on Urban Problems, The Challenge of America's Metropolitan Population Outlook, 1960-1968, Washington, 1968 .

${ }^{10}$ National Goals Research Staff, Toward Balanced Growth: Quantity With Quality, "Population Growth and Distribution," Chapter 2 (Washington: Superintendent of Documents, U.S. Government Printing Office, July 1970), p. 42.

11 Peter Morrison, "The Rationale for a Policy on Population Distribution," Papers and Proceedings, American Political Science Association, Los Angeles, 1970 .

${ }^{12}$ Lincoln and Alice Day recently pointed out some of the significant changes that are taking place in the age composition of the nation's population. According to the Day's the number of people reaching the age of 21 in 1967 was 
85 percent higher than the number reaching that age in the mid-50's, and this level of increase will probably be sustained for the next 15 years. Moreover, the number of women of child bearing age will have risen by nearly 40 percent by 1980 , thus making it even more difficult to develop a policy of population stabilization in the near future. See Lincoln H. Day and Alice Taylor Day, The Demographic Perspective, Statement before Conservation and Natural Resource Subcommittee of the Committee of Government Operations of the Congress of the United States, House of Representatives, September 16, 1969.

13

This is not to say that other presidents in recent years have notbeen concerned with population problems. Both Eisenhowerand Kennedy expressed grave concern over the growing population pressure on the food supply in underdeveloped countries. President Johnson initiated a number of government-sponsored birth control clinics for disadvantaged women in the U.S. and was actually the first president to carry out a formal population stabilization program within the U.S.

${ }^{14}$ Social Security Administration's 1\% Work History Sample, 90 Selected SMSA's.

${ }^{15}$ The magnitude of the migration flows likely to develop in the 70 's perhaps also explains why some groups are working towards establishing 50 or 100 entirely new communities.

${ }^{16}$ This is not to suggest that the zero population growth concept does not hold certain desirable qualities.

17 The selective nature of migration is a well established fact. See Bureau of the Census, "Mobility of the Population of the United States, April 1958 to 1959, " Current Population Report, Series P-20, No. 104 (September 30, 1960), Table 4 .

18 Many studies suggest that mobility is rational in that behavior conforms to that predicted by wage theory. See Robert L. Raimon, "Interstate Migration and Wage Theory," Review of Economics and Statistics, November 1962, George P. Shultz, "A Nonunion Market for White-Collar Labor, "Aspects in Labor Economics; F. F. Foltman, White and Blue Collars in a Mill Shut Down (Ithaca, New York: New York State School of Industrial Relations, 1968); Stoikov and Raimon, "Determinants of Differences in the Quit Rate,' American Economic Review, March 1958; and see the exchange between James Tower, "Metropolitan Area Intercounty Migration Rates: A Test of Labor Market Theory," Industrial and Labor Relations Review, January 1965; and Kaun and Ferter, "Comment, "Industrial and Labor Relations Review, January 1966.

${ }^{19}$ This model is similar to Bevars D. Mabry's collective bargaining model. See Bevars D. Mabry, "The Pure Theory of Bargaining, "Industrial and Labor Relations Review, XVIII, No. 4 (July 1965), 479-502.

${ }^{20}$ The conditions for equilibrium are met where $\mathrm{N}_{\mathrm{p}}=\mathrm{N}_{\mathrm{s}}$ and both $\mathrm{N}_{\mathrm{p}}$ and $\mathrm{N}_{\mathrm{S}}$ equal zero. Where $\mathrm{N}_{\mathrm{p}}$ is equal to $\mathrm{N}_{\mathrm{s}}$ but both variables are greater or less than zero, an unstable equilibrium exists which will eventually result in net out- or in-migration. In addition to the schemes noted above, various unstable equilibrium positions are possible but are reserved for discussion in another paper.

${ }^{21}$ The problem of equating private and social costs has been reviewed by R. H. Coase, "The Problem of Social Cost," Journal of Law and Economics, 
Vol. III, October 1960, 1-44. Taxes or subsidies, as the case may be, may correct the apparent disequilibrium between private and social returns to migration.

22

The dependency ratio is defined as the ratio of persons aged 20-64 to the number of persons $0-19$, plus persons 65 and over.

${ }^{23}$ U.S. Bureau of the Census Population Reports, Series P-25, No. 415, January 31, 1962, Table A-2.

24 It should be pointed out, however, that many Federal government programs actually foster population concentration instead of population spread. Highway programs are a prime example of this "policy of concentration." Since the bulk of general transportation funds are allocated to those states and metropolitan regions which already have the largest populations.

25 On the effects of tax subsidies or housing consumption and resource allocation, see Henry Arron, "Income Taxes and Housing, "American Economic Review, December 1970, pp. 789-805.

${ }^{26}$ Kingsley Davis, "Population Policy: Will Current Programs Succeed?" Science, Vol. 158, November 1967, p. 732.

27 Much of the recent family planning effort has been aimed at low income families; however, it is the non-poor families who have the highest percentage share of total births (68.2 percent of all births in 1966). These families moreover, want more than two children and can also afford them; therefore, excess births per family are as much if not more of a problem of the mid-dle and upper income classes as they are of the poor. cf. Arthur Campbell, "The Role of Family Planning," Journal of Marriages and the Family, Vol. XXX, No. 2, 1968 .

28 Lincoln and Alice Day, op. cit. p. viii.

${ }^{29}$ All of these proposals have come under criticism for one reason or another. The development of small towns and ruralplaces has been criticized on the grounds that most growth industries simply could not operate effectively in a rural or small town setting because of the lack of sufficient "externalities." The new community concept has been labeled by many as a "federal pipedream." Indeed, it would appear doubtful that the complexeconomic and institutional linkages necessary for the development of such communities could be workedout quickly or even efficiently; the refore, it is unlikely this type of program would have much bearing on population distribution over the next 30 years. The growth center strategy appears more likely to succeed because many of the basic economic and institutional linkages have already been established. Moreover, the level of public expenditure required to sustain or encourage the development of existing growth centers couldwell be only a fraction of that for new communities.

30 The private and social returns to migration will determine the actual movement.

${ }^{31_{W}}$ illiam Coleman, 'Needed: A National and State Urban Growth Policy, "National Association of County Official News, January 1971, p. 9.

${ }^{32}$ Peter Morrison, op. cit. p. 16.

${ }^{33}$ The critical issue here, of course, is the nature of the impact the policy variables will have on a region's level of social and economic welfare. Do we know, for example, what effect a zero population growth will really 
have on the quality of the physical and social environment or the rate of economic growth? Obviously we do not, for our limited experience in the area of population planning does not allow us to determine a priori the effects of such policy decisions. Nevertheless, this should not deterusfromestablishing the policy model--indeed our limited understanding of the effects of population on the physical, social, and economic environment is the very reason it should be constructed! 